\title{
Economic and Productive Assessment of an Ordinary Small-Sized Dairy Enterprise in Southeast Brazil: A Multi-Year Study
}

\author{
Severino D. J. Villela ${ }^{1}$, Leandro P. Assis ${ }^{1}$, Marcos A. Lopes ${ }^{2}$, Luiz H. A. Silvestre ${ }^{1}$, Roseli A. Santos ${ }^{1}$, \\ Elton S. Resende ${ }^{1} \&$ Paulo G. M. A. Martins ${ }^{1,3}$ \\ ${ }^{1}$ Department of Animal Science, Federal University of Jequitinhonha and Mucuri Valleys, Diamantina, Brazil \\ ${ }^{2}$ Department of Veterinary Medicine, Federal University of Lavras, Brazil \\ ${ }^{3}$ Federal Institute of Northern Minas Gerais, Almenara, Brazil \\ Correspondence: Paulo G. M. A. Martins, Federal Institute of Northern Minas Gerais, Almenara, MG 39900-000, \\ Brazil. E-mail: paulo.martins@ifnmg.edu.br
}

\author{
Received: April 29, 2017 \\ Accepted: June 13, $2017 \quad$ Online Published: July 15, 2017 \\ doi:10.5539/jas.v9n8p143 \\ URL: https://doi.org/10.5539/jas.v9n8p143
}

\begin{abstract}
The objectives were to analyze the economic performance over time of a dairy enterprise located in southeast Brazil and to identify the key production parameters that contributed to economic performance, using a 10-year database. Two distinct approaches to evaluate production cost were analyzed. Briefly, the first approach involves variable and fixed costs (more traditional economic analysis), and the second involves total operating cost, consisting of effective operating costs and depreciation. From these two distinct approaches, we obtain as economic indicators the profitability I and profitability II, respectively. In addition, correlation between economic and productivity parameters was performed. Considering the first approach, revenue was not sufficient to cover the total cost and on average profitability I was negative. During three years, the break-even point was not achieved. Considering the second approach, gross profit margin was positive throughout the period, and consequently profitability II was positive. In general, production parameters were within the ordinary range observed in small-sized Brazilian dairy farms. From the correlations between economic and production parameters, we noted that correlation between average milk production per lactating cow and both measures of profit was present, indicating that if the average milk production per lactating cow was high, profit was positive. We conclude that this type of evaluation is important to assess the performance of a business, and consequently, for decision-making of dairy producers.
\end{abstract}

Keywords: correlation, economic viability, production costs, production parameters

\section{Introduction}

Brazil is among the top five milk-producing countries worldwide, producing approximately 31 million tons annually (Food and Agriculture Organization [FAO], 2013). Dairy production is an important agricultural activity in Brazil, and Minas Gerais, located in the southeast, is the greatest milk producing state, producing 1.7 billion L in the first quarter of 2014 (Instituto Brasileiro de Geografia e Estatística [IBGE], 2014). Notwithstanding, milk production within the state is very diverse, and profitability of the activity also differs among the different production systems. Because of low returns, dairy enterprise owners need to know the cost of variables they can control as a strategy to remain competitive, and achieve lower production costs. Therefore, periodic analysis of economic and production efficiency should be performed. Nevertheless, we observe in the practice that few small- and medium-sized dairy enterprises conduct this analysis, and production costs are unknown. In addition, it is important to determine which production parameters most affect the economic parameters of a dairy enterprise.

Determining production costs is a complex task for an ordinary dairy producer not only in Brazil because it requires collection of very detailed data. In our experience, very few Brazilian producers perform such data collection, particularly over an extended period of time. Attention should be addressed when collecting the data, because a small error can lead to an incorrect diagnosis of the production system. There is limited information about economic evaluations and factors that affect small- (production of up to $50 \mathrm{~L}$ of milk per day) and medium-sized (production of up to $500 \mathrm{~L}$ of milk per day) dairy farming in Brazil, and also the relation between 
economic and production parameters. Accordingly, our objectives were to analyze the economic performance over time of a dairy enterprise located in southeast Brazil and to identify the key production parameters that contributed to economic performance.

\section{Material and Methods}

Institutional animal care and use committee approval was not requested for the present study because the data were provided by the producer who owns the dairy enterprise. A 10-year database (from January 2002 until December 2011) from a commercial dairy enterprise, located in Minas Gerais state, Brazil $\left(43^{\circ} 28^{\prime} \mathrm{W}\right.$ and $18^{\circ} 04^{\prime} \mathrm{S}$ ), was evaluated. Unlike other small-sized dairy enterprises, this particular farm had this database because the owner was a veterinarian who collected this type of data when he assisted other farmers. Data regarding production parameters, expenditure, and revenue, recorded in the Prodap Profissional ${ }^{\mathbb{R}}$ (Prodap Ltda., Belo Horizonte, MG, Brazil) computer software, were summarized in a Microsoft Excel (Microsoft Corp., Redmond, WA, USA) spreadsheet, specially developed for this purpose.

\subsection{Description of the Dairy Enterprise, and Management}

The evaluated enterprise is a good representative of a typical, small-sized, dairy farm encountered in Minas Gerais state, as well as in the rest of Brazil. Total area utilized for dairy production was 225 ha, in which 49 ha were for rotational grazing of Tanzania grass (Panicum maximum) pasture, 169 ha, Brachiaria brizantha and Brachiaria humidicola, 4 ha, elephant grass (Pennisetum purpureum) and sugarcane (Saccharum officinarum), and 3 ha used for facilities. These roughage sources were utilized during the entire period for the herd feeding. The farm had four employees during the 10-year period. The facility employed for production did not change throughout the period, and consisted of a simple corral where employees performed milking, feeding, and animal handling. Overall, the infrastructure production system did not change significantly during the studied period.

The structure of the herd, consisted of crossbred (Gyr $\times$ Holstein) animals, is depicted in Table 1 . The herd was self-replacing, and the cows calved year round, as is typical in Brazilian dairy production systems. All animals were kept on the aforementioned pastures throughout the day, and supplementary feed, consisting of $85 \%$ of corn and $15 \%$ of soybean meal, was provided after milking. The amount of supplement provided varied according to milk production, lactation day, body condition score, cow parity, and forage quality. Based on forage quality, the potential of milk production of each cow was estimated, and $1 \mathrm{~kg}$ of concentrate supplement was provided for each $2.5 \mathrm{~L}$ of milk produced above the estimated milk production (i.e., which would be produced only if cows were kept in pasture without supplementation). Cows were milked twice daily using a direct-to-bucket milking machine equipment. Management actions regarding animal health, milking hygiene, nutrition, environment management, and animal welfare were performed according to the Guide to Good Dairy Farming Practice (FAO $\&$ International Dairy Federation [IDF], 2011). Cows underwent up to three rounds of artificial insemination and were run with bulls if they did not become pregnant. Vaccinations against foot-and-mouth disease (caused by Aphthae epizooticae), blackleg (caused by Clostridium chauvoei), and brucellosis (caused by Brucella abortus) were performed based on local law regulation. Endo- and ecto-parasites were systematically controlled. Milk production (recorded monthly), vaccinations, calf births, mating, revenue, and expenses were precisely recorded.

Table 1. Herd structure of a dairy enterprise, located in Minas Gerais state, Brazil $\left(43^{\circ} 28^{\prime} \mathrm{W}\right.$ and $\left.18^{\circ} 04^{\prime} \mathrm{S}\right)$, between 2002 and 2011

\begin{tabular}{lllllllllll}
\hline Animal category & 2002 & 2003 & 2004 & 2005 & 2006 & 2007 & 2008 & 2009 & 2010 & 2011 \\
\hline Calves & 72 & 48 & 76 & 84 & 76 & 85 & 83 & 87 & 98 & 110 \\
Heifers & 8 & 36 & 16 & 28 & 44 & 31 & 29 & 31 & 19 & 8 \\
Mature cows & 88 & 76 & 101 & 89 & 103 & 110 & 110 & 126 & 126 & 118 \\
Teaser bulls & 6 & 5 & 5 & 8 & 9 & 10 & 10 & 8 & 8 & 4 \\
Bulls & 1 & 1 & 1 & 7 & 11 & 15 & 13 & 8 & 3 & 0 \\
Total & 175 & 166 & 199 & 216 & 243 & 251 & 245 & 260 & 254 & 240 \\
\hline
\end{tabular}

Note. Number of animals is related to what was encountered in the first day of each year.

\subsection{Production Costs Assessment}

Production costs assessment was performed for each year to evaluate how the farm changed over the 10-year period. Revenue was defined as the gross farm income (cash inflows) from milk, by-products and cattle sales. We also considered as a source of income the variation of animal inventory, which was obtained by subtracting 
the animal inventory of the previous year from the animal inventory of the current year. This approach was considered because the enterprise had a non-stabilized herd. Our definitions were based on descriptions in the Farm Financial Standards Council (2011), except that we did not account government payments because the producer did not receive such income.

Two distinct approaches to evaluate production cost were analyzed: 1) total cost (expenses), which involves variable and fixed costs (more traditional economic analysis; Reis, Medeiros, \& Monteiro, 2001); and 2) operating costs, an alternative economic analysis proposed by Matsunaga et al. (1976) which involves total operating cost, consisting of effective operating costs and depreciation. The reasons of choosing these two approaches are that they are commonly used in Brazil when analyzing agricultural enterprises. In the first approach, variable costs included feed, animal health and laboratory analysis, labor, maintenance of machinery and equipment, professional consulting services, and income tax. For labor costs, we considered the costs of wages, outsourced services, and related social security charges. Fixed costs included depreciation, fixed taxes (i.e., Brazilian tax on rural property), and interest paid relative to capital invested in facilities, machinery, equipment and estate. In accordance with Lopes, Santos, Resende, Carvalho, and Cardoso (2011), we utilized a $6 \%$ annual interest rate as the cost of capital invested in the dairy activity. Estate costs were achieved from the value paid for leasing $1 \mathrm{ha}$, which was converted to liters of milk per ha per day, based on average values in the region (Lopes et al., 2011). For this approach, we denominate as profitability I as the result obtained by dividing net profit by working capital, which corresponds to all capital immobilized with the production assets. From the division of total cost into fixed and variable, we can identify the break-even point (Potkanya \& Krajcirova, 2015). Thus, break-even point was estimated according to the following equation described by Lopes et al. (2011):

$$
\text { Breakeven point }=\frac{\text { Fixed cost }}{\text { Milk price-variable cost of } 1 \mathrm{~L} \text { of milk }}
$$

In the second approach, total operating costs were considered expenses which were related with operation of the enterprise, consisting of effective operating costs and depreciation. Effective operating costs were all expenses the producer has to disburse (Nogueira, 2004). The linear method described by Nogueira (2004) was utilized to calculate depreciation expenses. Cow depreciation was not considered in composing costs. To clear represent this second approach, the following equations are presented:

$$
\begin{gathered}
\text { Total operating cost }=\text { Effective operating cost }+ \text { Depreciation } \\
\text { Effective operating cost }=\text { Disbursement }
\end{gathered}
$$

Gross profit margin was obtained by subtracting the effective operating costs from revenue, and indicates the residue from revenue when only disbursements are considered. Net profit margin was the residue obtained from revenue minus total operating cost. From this alternative approach, we utilized a new analysis tool to assess profitability which we denominated profitability II. Profitability II was obtained by dividing net profit margin by working capital (Lopes et al., 2011).

A stratification of components of the effective operating cost over the years was performed to identify the percentage of each item of this cost (see Table 3).

\subsection{Production Parameters}

The following items were evaluated as production efficiency parameters: 1) percentage of cows in lactation; 2) days of lactation; 3) daily milk production of the herd; 4) average milk production of the herd; 5) average milk production per lactating cow; 6) calving interval; 7) milk production per ha; 8) milk production:concentrate ratio; 9) milk production:employee ratio; and 10) cows:employee ratio. These parameters are typically evaluated in Brazil to assess reproduction performance (e.g., percentage of cows in lactation, days of lactation, and calving interval), genetics (e.g., average milk production per cow), nutrition (e.g., average milk production per cow and milk production: concentrate ratio), and overall performance (e.g., milk production per ha, milk production: employee ratio, and cows: employee ratio).

\subsection{Statistical Analysis}

Production parameters and milk price were correlated with economic efficiency parameters (total cost; total operating cost; effective operating cost; gross profit margin; net profit margin; and profitability I and II) using the Pearson correlation analysis. The CORR procedure of SAS (SAS Institute Inc., Cary, NC, USA) was utilized for the analysis. Significance was set at $P \leq 0.05$. 


\section{Results}

\subsection{Production Costs}

Average milk price per liter and economic parameters are depicted in Table 2. Analyzing the first approach, over the 10 -year period, revenue was not sufficient to cover the total cost. On average, profitability I was negative. In the years of 2002, 2003 and 2007, break-even point was not achieved.

For the second approach, gross profit margin was positive throughout the period, and net profit margin, on average, was positive; only in 2002 and 2007 this item was negative. Consequently, over the 10-year period on average, profitability II was positive, with 2002 and 2007 also being negative. Analyzing the percentage of each item of the effective operating cost, feeding and labor were more representative (Table 3). Both items together accounted over the 10 -year period for $70.8 \%$ of the effective operating cost. During 2002, we observed a greater expense with labor (42.5\%) compared with other years, and other items. The third more costly item was animal health, with an average of $7.3 \%$. Artificial insemination costs were greater in 2003, with consequent decrease in the participation over the subsequent years. The other items (energy and fuel, taxes, maintenance, and miscellaneous) accounted together for $18.3 \%$ on average.

\subsection{Production Parameters}

Production parameters are described in Table 4. Percentage of cows in lactation over the years increased from 56.7 in 2002 to 75.5 in 2011, with a peak in 2009. On average, the 'days of lactation' parameter was 169.4, with 2006 having the least value (133 days). In 2009, daily milk production of the herd was greatest $(1050 \mathrm{~L})$ and in 2002 was the least (426 L). Average milk production of the herd also achieved the greatest value in 2009. Average milk production per lactating cow was, on average, $10.1 \mathrm{~L}$. Calving interval was the shortest in the first year of analysis and the longest was in 2006, with an average of 492 days. Similarly to average milk production per lactating cow, milk production per ha was greatest in 2009. In the system evaluated herein, cows were kept on pasture and were provided with a supplementary concentrate diet, and $2.9 \mathrm{~L}$ of milk were produced for each $\mathrm{kg}$ of supplementary concentrate provided to cows. In the present study, forage intake was not measured, but it has contributed to the milk produced. In 2008, milk production per $\mathrm{kg}$ of concentrate, and milk production:employee ratio were the greatest. Average milk production per employee was $333 \mathrm{~L} / \mathrm{day}$. Cow per employee ratio was greater than 60 just in 2005 and 2006, with an average of $49.5 \mathrm{~L} / \mathrm{employee}$.

\subsection{Correlation between Economic and Production Parameters}

Correlations are described in Table 5. There was no correlation between cows in lactation and net profit margin $(P=0.07)$, profitability I $(P=0.23)$ and profitability II $(P=0.16)$. However, correlation between this item and total cost, total operating cost, effective operating cost, and gross profit margin was detected $(P<0.05)$. No correlation $(P>0.37)$ between days of lactation and economic parameters was detected. No correlation $(P>0.08)$ between daily milk production of the herd and profitability I and II was observed; however, correlations were observed for total cost $(P<0.001)$, total operating cost $(P<0.001)$, effective operating cost $(P<0.001)$, gross profit margin $(P=0.02)$, and net profit margin $(P=0.03)$. Similarly, no correlation $(P=0.13)$ between average milk production of the herd and profitability I was observed, but for all other economical parameters, correlation was observed $(P<0.05)$. For average milk production per lactating cow, no correlation between total cost $(P=$ $0.15)$, total operating cost $(P=0.14)$, and effective operating cost $(P=0.15)$, but correlation with other parameters was detected $(P<0.04)$. Calving interval, milk production:concentrate ratio and cows:employee ratio did not $(P>0.32)$ correlate with any economic parameters. Correlation $(P<0.05)$ between milk production per ha and all economic parameters, except for profitability I $(P=0.07)$ was detected. Milk production:employee ration had correlation $(P<0.01)$ with total cost, total operating cost, and effective operating cost, but no correlation $(P>0.06)$ was observed for other parameters. And finally, milk price had medium correlation $(P=$ $0.05)$ with gross profit margin, and no correlation $(P>0.07)$ with net profit margin, and profitability I and II. 
Table 2. Average milk price paid to the producer and summary of economic parameters from a dairy enterprise, located in Minas Gerais state, Brazil (43 ${ }^{\circ} 28^{\prime} \mathrm{W}$ and $\left.18^{\circ} 04^{\prime} \mathrm{S}\right)$, between 2002 and 2011

\begin{tabular}{|c|c|c|c|c|c|c|c|c|c|c|c|c|}
\hline Item & 2002 & 2003 & 2004 & 2005 & 2006 & 2007 & 2008 & 2009 & 2010 & 2011 & Average & $\begin{array}{l}\text { Standard } \\
\text { deviation }\end{array}$ \\
\hline $\begin{array}{l}\text { Average milk price } \\
\text { (R\$ per liter) }\end{array}$ & 0.35 & 0.47 & 0.5 & 0.53 & 0.46 & 0.65 & 0.69 & 0.65 & 0.68 & 0.77 & 0.58 & 0.132 \\
\hline Revenue (R\$) & $105,569.44$ & $148,770.47$ & $222,929.46$ & $176,487.10$ & $177,511.91$ & $203,438.58$ & $296,345.63$ & $304,487.42$ & $291,584.97$ & $319,052.77$ & $224,617.78$ & $74,415.40$ \\
\hline Milk (R\$) & $48,740.85$ & $89,542.57$ & $114,660.33$ & $103,852.78$ & $84,084.93$ & $141,115.99$ & $202,289.60$ & $207,694.68$ & $201,176.15$ & $219,151.19$ & $141,230.91$ & $61,829.06$ \\
\hline Animals (R\$) & $25,140.25$ & $14,354.79$ & $22,987.13$ & $47,008.32$ & $88,310.74$ & $32,202.59$ & $87,205.81$ & $79,532.15$ & $75,088.82$ & $29,601.58$ & $50,143.22$ & $29,275.42$ \\
\hline By-products (R\$) & 498.34 & 501.11 & 0.00 & 0.00 & 86.24 & 0.00 & 900.23 & $2,930.59$ & 0.00 & 0.00 & 491.65 & 912.17 \\
\hline $\begin{array}{l}\text { Variation in animal } \\
\text { inventory }(\mathrm{R} \$)\end{array}$ & $31,190.00$ & $44,372.00$ & $85,282.00$ & $25,626.00$ & $5,030.00$ & $30,120.00$ & $5,950.00$ & $14,330.00$ & $15,320.00$ & $70,300.00$ & $32,752.00$ & $26,862.87$ \\
\hline \multicolumn{13}{|l|}{ First approach } \\
\hline Total costs $(\mathrm{R} \$)$ & $177,135.15$ & $209,192.21$ & $235,470.35$ & $245,418.05$ & $250,147.45$ & $316,546.38$ & $363,243.67$ & $356,751.99$ & $358,200.84$ & $371,504.29$ & $2,883,610.38$ & $288,361.03$ \\
\hline Variable costs $(\mathrm{R} \$)$ & $105,625.03$ & $117,141.15$ & $133,985.49$ & $138,836.40$ & $145,605.98$ & $195,961.30$ & $230,281.28$ & $228,203.92$ & $224,599.83$ & $226,723.16$ & $1,746,963.54$ & $174,696.35$ \\
\hline Fixed costs (R\$) & $71,510.12$ & $92,051.06$ & $101,484.86$ & $106,581.65$ & $104,541.47$ & $120,585.08$ & $132,962.39$ & $128,548.07$ & $133,601.01$ & $144,781.13$ & $1,136,646.84$ & $113,664.68$ \\
\hline Workig capital & $654,855.67$ & $793,481.99$ & $919,833.2$ & $977,228.41$ & $1,029,944.03$ & $1,079,395.96$ & $1,182,595.89$ & $1,211,031,92$ & $1,258,957.95$ & $1,344,888.98$ & $1,045,221.4$ & $215,858.37$ \\
\hline Profitability I (\%) & -10.93 & -7.61 & -1.36 & -7.05 & -7.05 & -10.48 & -5.66 & -4.32 & -5.29 & -3.9 & -6.37 & 2.93 \\
\hline Break-even point $(\mathrm{L})^{1}$ & - & - & $7,629,299.65$ & $2,522,955.08$ & $1,458,514.77$ & - & $930,875.61$ & $926,232.45$ & $1,050,579.83$ & $2,123,157.96$ & $1,313,063.04$ & $2,616,637.61$ \\
\hline \multicolumn{13}{|l|}{ Second approach } \\
\hline $\begin{array}{l}\text { Total operating } \\
\operatorname{cost}(\mathrm{R} \$)\end{array}$ & $123,834.74$ & $141,416.38$ & $160,129.51$ & $163,140.63$ & $171,100.29$ & $218,702.65$ & $257,274.91$ & $253,527.25$ & $251,069.59$ & $254,332.55$ & $199,452.85$ & $52,777.47$ \\
\hline $\begin{array}{l}\text { Effective operating } \\
\operatorname{cost}(\mathrm{R} \$)\end{array}$ & $103,661.05$ & $114,685.59$ & $133,398.72$ & $136,409.84$ & $143,932.22$ & $191,534.58$ & $226,380.94$ & $222,633.28$ & $219,200.62$ & $222,263.58$ & $171,410.04$ & $49,613.10$ \\
\hline $\begin{array}{l}\text { Gross profit } \\
\text { margin (R\$) }\end{array}$ & $1,908.39$ & $34,084.88$ & $89,530.74$ & $40,077.26$ & $33,579.69$ & $11,940.00$ & $69,964.69$ & $81,854.14$ & $72,384.35$ & $96,789.19$ & $53,207.73$ & $33,247.95$ \\
\hline $\begin{array}{l}\text { Net profit } \\
\text { margin (R\$) }\end{array}$ & $-18,265.30$ & $7,354.09$ & $62,799.95$ & $13,346.47$ & $6,411.62$ & $-15,264.07$ & $39,070.72$ & $50,960.17$ & $40,515.38$ & $64,720.22$ & $25,164.93$ & $30,559.04$ \\
\hline Profitability II (\%) & -2.79 & 0.93 & 6.83 & 1.37 & 0.62 & -1.41 & 3.30 & 4.21 & 3.22 & 4.81 & 2.11 & 2.93 \\
\hline
\end{tabular}

Note. R\$: Brazilian currency (Real). Prices are in the value of the day.

${ }^{1}$ When milk price were less than variable cost of $1 \mathrm{~L}$ of milk, the break-even point is negative (i.e., it is not achievable).

Table 3. Percentage composition of the effective operating cost from a dairy enterprise located in Minas Gerais state, Brazil ( $43^{\circ} 28^{\prime} \mathrm{W}$ and $\left.18^{\circ} 04^{\prime} \mathrm{S}\right)$, between 2002 and 2011

\begin{tabular}{lllllllllllll}
\hline Item (\%) & 2002 & 2003 & 2004 & 2005 & 2006 & 2007 & 2008 & 2009 & 2010 & 2011 & Average & SD \\
\hline Feeding & 24.6 & 23.3 & 29.5 & 29.3 & 38.7 & 42.5 & 46.8 & 47.8 & 43.7 & 42.7 & 36.9 & 8.8 \\
Labor & 42.5 & 40.4 & 32.9 & 33.3 & 33.0 & 31.9 & 33.0 & 28.7 & 31.8 & 31.1 & 33.9 & 4.0 \\
Animal health & 8.3 & 6.4 & 8.1 & 8.6 & 6.7 & 6.0 & 6.1 & 7.4 & 7.0 & 7.9 & 7.3 & 0.9 \\
Artificial insemination & 5.0 & 7.4 & 6.4 & 4.2 & 3.4 & 1.8 & 2.0 & 2.2 & 2.1 & 2.5 & 3.7 & 1.9 \\
Energy and fuel & 2.2 & 6.6 & 5.3 & 5.8 & 6.3 & 6.2 & 3.9 & 4.2 & 3.6 & 4.6 & 4.9 & 1.3 \\
Taxes & 1.1 & 0.8 & 2.5 & 1.2 & 1.8 & 0.7 & 1.2 & 0.5 & 0.5 & 1.0 & 1.1 & 0.6 \\
Maintenance & 4.0 & 3.4 & 2.8 & 4.3 & 3.7 & 6.7 & 3.0 & 4.5 & 6.4 & 4.3 & 4.3 & 1.2 \\
Miscellaneous & 12.3 & 11.7 & 12.5 & 13.3 & 6.4 & 4.2 & 4.0 & 4.7 & 4.9 & 5.9 & 8.0 & 3.7 \\
\hline
\end{tabular}


Table 4. Production parameters from a dairy enterprise collected between 2002 and 2011

\begin{tabular}{lllllllllllll}
\hline Item (\%) & 2002 & 2003 & 2004 & 2005 & 2006 & 2007 & 2008 & 2009 & 2010 & 2011 & Average & SD \\
\hline Cows in lactation (\%) & 56.7 & 57.7 & 61.3 & 57.7 & 63.1 & 68.1 & 72.2 & 76.2 & 72.1 & 75.5 & 66.1 & 7.67 \\
Days of lactation & 166 & 150 & 177 & 190 & 133 & 184 & 200 & 166 & 168 & 162 & 169.6 & 19.5 \\
Daily milk production of the herd (L) & 426 & 506 & 528 & 530 & 593 & 649 & 880 & 1050 & 940 & 917 & 701.9 & 218.3 \\
Average milk production of the herd (L) & 5.3 & 5.8 & 5.9 & 5.4 & 5.4 & 5.5 & 7.4 & 8.1 & 7.3 & 8.2 & 6.4 & 1.18 \\
Average milk production per lactating cow (L) & 9.6 & 10.5 & 10.3 & 9.4 & 9.1 & 8.7 & 10.9 & 10.8 & 10.5 & 11.3 & 10.1 & 0.86 \\
Calving interval (days) & 425 & 475 & 439 & 497 & 579 & 548 & 545 & 509 & 447 & 436 & 490.0 & 58.6 \\
Milk production per ha (L) & 619 & 847 & 1019 & 871 & 617 & 965 & 1303 & 1420 & 1315 & 1265 & 1024.1 & 291.7 \\
Milk production:concentrate ratio (L/kg) & 3.1 & 3.0 & 3.0 & 2.5 & 2.6 & 2.6 & 3.5 & 3.1 & 2.8 & 2.9 & 2.9 & 0.28 \\
Milk production:employee ratio (L) & 213 & 253 & 296 & 348 & 382 & 292 & 407 & 397 & 393 & 351 & 333.2 & 66.4 \\
Cows:employee ratio & 41 & 40 & 50 & 63 & 66 & 48 & 54 & 46 & 49 & 40 & 49.7 & 9.1 \\
\hline
\end{tabular}

Table 5. Correlations between production and economic parameters from a dairy enterprise, during 2002-2011

\begin{tabular}{llllllll}
\hline & Total cost & $\begin{array}{l}\text { Total operating } \\
\text { cost }\end{array}$ & $\begin{array}{l}\text { Effective operating } \\
\text { cost }\end{array}$ & $\begin{array}{l}\text { Gross profit } \\
\text { margin }\end{array}$ & $\begin{array}{l}\text { Net profit } \\
\text { margin }\end{array}$ & $\begin{array}{l}\text { Profitability } \\
\text { I }\end{array}$ & $\begin{array}{l}\text { Profitability } \\
\text { II }\end{array}$ \\
\hline Cows in lactation & $0.97^{* * *}$ & $0.97^{* * *}$ & $0.97^{* * *}$ & $0.64^{*}$ & $0.60^{\mathrm{NS}}$ & $0.48^{\mathrm{NS}}$ & $0.48^{\mathrm{NS}}$ \\
Day of lactation & $0.30^{\mathrm{NS}}$ & $0.30^{\mathrm{NS}}$ & $0.31^{\mathrm{NS}}$ & $0.13^{\mathrm{NS}}$ & $0.12^{\mathrm{NS}}$ & $0.04^{\mathrm{NS}}$ & $0.14^{\mathrm{NS}}$ \\
Daily milk production of the herd & $0.93^{* * *}$ & $0.95^{* * *}$ & $0.95^{* * *}$ & $0.72^{*}$ & $0.68^{*}$ & $0.51^{\mathrm{NS}}$ & $0.57^{\mathrm{NS}}$ \\
Average milk production of the herd & $0.85^{* *}$ & $0.86^{* *}$ & $0.85^{* *}$ & $0.79^{* *}$ & $0.76^{*}$ & $0.57^{\mathrm{NS}}$ & $0.63^{*}$ \\
Average milk production per & $0.49^{\mathrm{NS}}$ & $0.50^{\mathrm{NS}}$ & $0.49^{\mathrm{NS}}$ & $0.79^{* *}$ & $0.79^{* *}$ & $0.66^{*}$ & $0.69^{*}$ \\
lactating cow & & & & & & \\
Calving interval & $0.20^{\mathrm{NS}}$ & $0.20^{\mathrm{NS}}$ & $0.20^{\mathrm{NS}}$ & $-0.26^{\mathrm{NS}}$ & $-0.30^{\mathrm{NS}}$ & $-0.24^{\mathrm{NS}}$ & $-0.23^{\mathrm{NS}}$ \\
Milk production per ha & $0.88^{* * *}$ & $0.89^{* * *}$ & $0.88^{* *}$ & $0.79^{* *}$ & $0.75^{*}$ & $0.60 \mathrm{NS}$ & $0.68^{*}$ \\
Milk production:concentrate ratio & $0.18^{\mathrm{NS}}$ & $0.22^{\mathrm{NS}}$ & $0.23^{\mathrm{NS}}$ & $0.33^{\mathrm{NS}}$ & $0.35^{\mathrm{NS}}$ & $0.25^{\mathrm{NS}}$ & $0.29^{\mathrm{NS}}$ \\
Milk production:employee ratio & $0.77^{* *}$ & $0.77^{* *}$ & $0.76^{* *}$ & $0.60^{\mathrm{NS}}$ & $0.55^{\mathrm{NS}}$ & $0.50^{\mathrm{NS}}$ & $0.52^{\mathrm{NS}}$ \\
Cows:employee ratio & $-0.05^{\mathrm{NS}}$ & $0.06^{\mathrm{NS}}$ & $0.07^{\mathrm{NS}}$ & $-0.09^{\mathrm{NS}}$ & $-0.10^{\mathrm{NS}}$ & $0.04^{\mathrm{NS}}$ & $-0.003^{\mathrm{NS}}$ \\
Milk price & $0.96^{* * *}$ & $0.95^{* * *}$ & $0.94^{* * *}$ & $0.64^{*}$ & $0.59^{\mathrm{NS}}$ & $0.41^{\mathrm{NS}}$ & $0.51^{\mathrm{NS}}$ \\
\hline
\end{tabular}

Note. ${ }^{*} P<0.05 ; * * P<0.01 ; * * * P<0.001 ;{ }^{\text {NS }}$ non-significant.

\section{Discussion}

In Brazil, ordinary economic analysis of any business utilizes the total cost approach to assess economic performance. Theoretically, this approach considers variable and fixed costs, taking into account depreciation and opportunity cost of the working capital. In the 1970's, with an inflationary environment, the calculation of these costs were not practical. After analyzing variable and fixed costs, the capacity of decision making was hampered, thus producers had a difficulty in deciding whether to stay or leave the business. To overcome this situation, an alternative approach was proposed by Matsunaga et al. (1976). These authors considered the operating cost method which included only expenses effectively disbursed by the producer, plus depreciation rate of machinery and facilities. Nowadays, both approaches are used in Brazil to assess agricultural enterprises. Although some terms and definitions utilized in the present study do not follow a worldwide standard convention, they are usually employed in Brazil. There is a difficulty in publishing this type of data in international journals because of this misunderstanding. Nonetheless, this report is an attempt in sharing the concept of these approaches, making them available for English-speaking readers.

\subsection{Production Costs}

Because of revenue earned in the activity was not sufficient to cover the total cost, this explain why net profit was negative. We can state that there was no economic success of this particular dairy production since costs were greater than the ideal threshold for the observed level of production. In this manner, the profitability I was negative (-6.37\%); ideally, this profit should be $0 \%$ or above. A limitation is observed in this approach because when calculating total costs, an opportunity cost of $6 \%$ is accounted (Lopes et al., 2011), making it difficult to compare with other activities. In this situation, we observed a decapitalization of the producer over the years, which is commonly observed in smallholder enterprises (Reis et al., 2001). In efficient production systems, it is expected that supernormal profit occurs (profitability I $>0$ ), in which the activity is getting return greater than 
other alternatives of capital investment, indicating that the enterprise can expand in the medium and long terms (Leite, Barbosa, \& Campos, 2006). Assessing only revenue itself is not a good approach to evaluate a production system because increasing revenue is not exclusively beneficial from an economic standpoint. Therefore, it is important to compare the costs associated, i.e., the amount invested in the system.

Considering the second approach (Matsunaga et al., 1976), on average, revenue was greater than effective operating cost and total operating cost and consequently gross and net profit margins were positive. We can infer that a positive cash inflow occurred because of positive gross profit margin, and that depreciation was also paid since net profit margin was positive. In the long term, the producer would keep in the business; on the other hand, if the producer faced a negative gross profit margin, the best alternative would be to immediately perform a diagnosis to detect the issues and fix those (Lopes, Demeu, Nogueira, \& Santos, 2012). In a worst-case scenario, the solution would be to interrupt the activity (Oliveira, Cunha, Campos, Vale, \& Assis, 2007). In addition, the greater net profit margin is, the greater will be the business' economic performance. In efficient production systems, it is expected that gross profit margin would be elevated since part of the operating cost were not accounted. In this manner, we expected greater gross profit margin values over the 10 -year period. However, the great participation of feeding and labor in the effective operating cost contributed towards a low value (Table 3). Exceptionally in 2008 and 2009, gross profit margin was greatest because of improved use of labor. In these years, we observed that the milk production per $\mathrm{kg}$ concentrate was greatest and consequently more revenue from milk sales was obtained by the producer, contributing for a greater gross profit margin value.

This second approach has a limitation when only gross and net profit margins are evaluated because they represent only a numerical figure. For example, even positive, both margins could represent a lesser return value when compared with alternatives of investment of the working capital that could provide better results; this indicates that the enterprise is earning less return if compared with a situation in which the working capital is invested elsewhere (Reis, 2002). To overcome this limitation, the analysis of profitability (in this case we called profitability II) allows to compare the return of the capital invested in the business. In the current situation, the producer had a profitability of $2.11 \%$ on average for the 10 -year period, i.e., for each $\mathrm{R} \$ 100.00$ invested, he earned $\mathrm{R} \$ 2.11$ in a year. If the producer, for instance, invested his money in bank savings, he would earn $\mathrm{R} \$ 6.00$.

The profitability I accounts the opportunity cost previously determined (in the present study, $6 \%$ ) since net profit is in the numerator of the equation to calculate profitability I. Thus, when net profit is zero, this profitability is also zero. On the other hand, profitability II permits comparisons with other activities, i.e., the producer is allowed to know exactly what the percentage of return of the invested capital is. Therefore, in our opinion, profitability II is a better way to analyze overall economic performance, if compared with profitability I.

The scale of production impacts profitability of a dairy enterprise (T. B. A. Oliveira, Figueiredo, M. W. Oliveira, \& Nascif, 2001). For instance, if we consider only the last five years (2007 to 2011), we observe that in 2009 the producer received one of the least remunerations per liter of milk; however, in this same year, if we do not consider variation in animal inventory, the greatest net profit margin was achieved, suggesting that increasing the number of lactating cows and improving animal performance should be more universally adopted. Increasing herd size depends on investments (financial resources); and improving herd average milk production relies on herd genetics and feeding. Unfortunately, the producer was not able to invest since net margin was negative.

The break-even point of a rural enterprise is the level of production to be achieved when total costs are equal to revenue (Reis et al., 2001). Level of production above this threshold indicates positive economic performance (supernormal profit). This economic parameter is pointed out by Lopes and Carvalho (2001) as the least tool in analyzing economic performance, primarily when utilizing the first approach. In 2002, 2003 and 2007, according to the equation proposed by Lopes et al. (2011), the values obtained were negative; thus, the break-even point was not achievable. These negative values were due to the elevated unitary milk cost which was above the milk price (data not shown). In these years, disbursement was greater than the price paid for $1 \mathrm{~L}$ of milk paid to the producer. Two possibilities in achieving the break-even point in these years would be the producer either reduce the variable cost or be remunerated according to milk quality. During the 10-year period, the producer was not remunerated by milk quality. When the break-even point was achieved, the producer was efficient in controlling variable cost.

\subsection{Production Parameters}

Determining production parameters of dairy enterprises is important to evaluate overall performance, as well as economic efficiency (Lopes, Demeu, Santos, \& Cardoso, 2009). Generally, production parameters outlook production per cow and its reproductive potential, which is related with overall performance and efficiency of a certain dairy enterprise. 
Percentage of cows in lactation is a production parameter affected by calving interval and lactation persistence (Camilo Neto, Campos, Oliveira, \& Gomes, 2012). In addition, when the parameter 'days of lactation' is extended, it indicates that the period between calving and conception is also extended, i.e., the service period is long. Although lactation persistence was not evaluated in the present study, this parameter influence days of lactation and it is important because affect feed costs for individual lactations of 305 days, but for other lactation lengths, persistency has a greater impact on milk returns per lactation than on feed costs (Dekkers, Ten Hag, \& Weersink, 1998). In the present study, percentage of cows in lactation was greater than the average in Brazil, which was $50 \%$ (Faria \& Silva, 1996) as well as the average (65\%) for Minas Gerais state (Federação da Agricultura do Estado de Minas Gerais [FAEMG], 1996). However, our cooperating farm's percentage is lower than the recommended $(80 \%)$ and the benchmark $(83 \%)$ values reported by Leite et al. (2006). The average value observed herein is directly related to the number of days of lactation which is influenced by genetics (Facó et al., 2008), in addition to cow nutrition. According to these authors, Bos taurus $\times$ Bos indicus animals have less capacity to persist lactation compared with specialized dairy breeds. As percentage of cows in lactation is related with lactation persistency and consequently with days of lactation, values closer to 305 days of lactation and to 135 days of lactation would be desirable to obtain good production efficiency. However, we observed different values for this benchmark.

Improvement of the number of cows in lactation can be attained by the reduction of the calving interval. Calving interval is an important parameter because affects economic performance (Inchaisri, Jorritsma, Vos, van der Weijden, \& Hogeveen, 2010). According to these authors, increasing the calving interval resulted in greater economic loss. The greatest calving interval observed in 2006 was similar to those reported by Marques, Reis, Sáfadi, and Reis (2002) who found 19 months. We observed values greater than the recommended by Leite et al. (2006), which is between 390 and 420 days. Our values were similar to those reported by Mancio, Schiffler, and Londono-Hernández (1999) who assessed four dairy enterprises. Herd productivity is related to this parameter which directly affects the number of replacement heifers in the herd (Beretta, Lobato, \& Mielitz, 2001). The lowest calving interval, observed in 2002, is two months greater than the benchmark but similar to values reported by Moraes et al. (2004), who evaluated a herd composed by F1 Gyr and Holstein cows. A possible reason for the longer calving interval is related with the misuse of artificial insemination. The producer attempted to introduce this technology but it was not successful. Because of that, cows experienced greater service period.

For production systems with 300 and 1000 cows, Jarret (1997) suggested a cow per employee ratio of 66:1 and 111:1. During 2005 and 2006, this ratio was similar to the suggested values, but in other years was lesser. The average milk production per employee during the entire period was greater than the values reported by Schiffler et al. (1999) and Lopes et al. (2004) for production systems under grazing, semi-confinement and confinement conditions. Our values demonstrate that there was no employee idleness, but values were less than the benchmark of $400 \mathrm{~L} /$ day (Leite et al., 2006), except in 2008. The average milk production per ha found in the present study, associated with the number of cows per ha, demonstrates that the area employed to production was not fully utilized. As a comparison, Schiffler, Mancio, Gomes, and Queiroz (1999) reported milk production ranging from 2,946 to $7,704 \mathrm{~L} / \mathrm{ha} /$ day; these authors evaluated four intensive production systems that utilized rotational grazing.

Comparing the value of average milk production of the herd found in this study with the average value of different countries (IFCN Dairy Report, 2008), we noted that it was similar to Germany (800 L), less than Argentina $(2,208 \mathrm{~L})$ and much less than New Zealand $(4,100 \mathrm{~L})$. Nationwide, our values were greater than the Brazilian average (52 L; IBGE, 2008) and also greater if compared to the average of the state (184 L; FAEMG, 2006). Because this parameter presented a low standard deviation, we can infer that there were no huge variations in terms of management among years, even with changes in number of lactating cows in the herd and percentage of cows in lactation. Several factors can affect the average milk production of the herd including age, cow parity, pregnancy, peak lactation (Oliveira et al., 2007), in addition to environmental factors that directly interfere in availability and quality of feedstuffs. Although these factors were present during the evaluation period, animal handling and management were capable to mitigate the possible negative effects on that parameter Moreover, even with a numerical increase of milk production:employee ratio in the first years, animal handling and management were not impaired. In fact, in the first three years, milk production:employee ratio was considered low if we compare to data reported by Yamaguchi, Carneiro, and Carvalho (2008) who found $326.3 \mathrm{~L}$ of milk produced per employee.

In 2009 , the greatest value of average milk production per lactating cow was observed. Concomitantly, in this year, percentage of cows in lactation was the greatest, which resulted in greater daily milk production of the herd. 
Associated with this, a greater milk production:concentrate ratio was also observed. As a comparison, Lopes et al (2004), evaluating dairy production enterprises in the south of Minas Gerais state, reported average values of milk production per lactating cow of $9.65 \mathrm{~L}$. Although not evaluated in the present study, failure in efficiently utilization of pastures may have compromised the production efficiency of the enterprise. In a study conducted by Vilela, Lima, Resende, and Verneque (2006) who evaluated irrigated tropical forages, these authors reported stocking rate of 7.3 cows per hectare, average milk production per lactating cow of $14 \mathrm{~L}$, and annual milk production per hectare of 20,000 L. The values reported by Vilela et al. (2006) demonstrate the importance of forage management on achieving greater milk production in a dairy enterprise.

\subsection{Correlation between Economic and Production Parameters}

The inclusion or not of interest rate on capital invested as costs in the dairy business generated two different values of profitability (profitability I and II). Even with different values, both profitability values had no significant correlation with efficiency production parameters, which was the inverse of what was expected at the beginning of this study. However, both profitability values were correlated with average milk production per lactating cow, indicating that the greater the daily milk production of the cow is, more efficient the production system will be. This is commonly observed in the field, and is highly recommended by extension personnel to enhance production parameters in various production systems. In addition, average milk production per lactating cow had no correlation with total cost, total operating cost, and effective operating cost, demonstrating that this parameter was correlated only with income earning of the enterprise. Thus, the producer has to be careful when choosing the level of milk production in relation to the amount of capital invested.

Percentage of cows in lactation is a parameter that indicates efficiency of a certain production system (Oliveira et al., 2007). In the current case, we observed no correlation of this parameter with profitability I and II, probably because the lesser is the number of lactating cows, less number of calves will be produced, consequently less number of lactating cows at peak lactation and, therefore, less daily milk production and less income. Nevertheless, that percentage had a positive and high correlation with production costs (total operating cost, effective operating cost, and total cost), highlighting that utilization of this parameter is a key factor in assessing production cost. This is corroborated by the greater participation of feeding during periods of low production.

Lack of correlation between daily milk production of the herd and profitability I and II indicates that the producer is probably out of the economies of scale (Ferguson, 1975). In this scenario, the improvement of production leads to an increase less than proportional of the cost and, consequently, increases more than proportional in profit. For the remainder economic parameters, we did observe correlation, indicating the direct participation of daily milk production of the herd as production cost constituent. Similarly, Almeida, Ramires, Jerszurki, Navarro, and Ostrensky (2009), evaluating 43 dairy enterprises in the Brazilian state of Paraná, reported that there was a positive correlation between level of milk production of the herd and gross profit margin.

Commonly, milk production:employee ratio is utilized as a parameter to evaluate efficiency of a dairy enterprise (Shoemaker et al., 2008). Fassio, Reis, and Geraldo (2006) considered the productiveness of the employees as one of the three major factors determining profitability of dairy production systems of the Minas Gerais state, which is the state where the enterprise evaluated hereinis located. However, we did not found significant values for this ratio $(P>0.07)$ when correlated with gross profit margin, net profit margin, and profitability I and II. Our values are in contrast to what reported by Oliveira et al. (2007) who found a positive correlation with profitability I in dairy enterprises located in the Brazilian state of Bahia.

Historically, milk price has been cited by producers as the main pretext of failure in dairy farming (FAEMG, 1996). However, in the present study, this item was not correlated with profitability I and II probably because when milk price was great, costs were also great and vice versa, i.e., when costs were lower, milk price was also lower. During off season periods, production cost is high, milk production slightly decrease and consequently milk price increases. Conversely, when production cost is low, producers increase milk production and then milk price decrease. Probably, these factors explain why milk price and profitability I and II were not correlated.

\section{Conclusions}

Production efficiency is a decisive factor for the competitiveness of the dairy sector in Brazil. Hence, cost management and systematization of production is essential to achieve this goal. Considering profitability I that on average for the 10-year period was negative, we observe that revenue was not sufficient to cover the total costs. Nonetheless, from the positive values of gross profit margin and net profit margin, we can infer that the producer was able to stay in business, however, the low average value of profitability II indicates that if the capital were invested in another manner (e.g., bank savings), a greater return would occur results based on 
annual interest rate practiced in Brazil. In general, production parameters are within the ordinary range observed in small-sized Brazilian dairy farm. From the correlations between economic and production parameters, we note that correlation between average milk production per lactating cow and both profitabilities was present, indicating that, if the average milk production per lactating cow were high, a positive reflex would be observed in profitability. Finally, we conclude that this type of evaluation is important to assess the performance of a business, and consequently, for decision-making of dairy producers.

\section{Acknowledgements}

The authors thank the Brazilian funding agency CAPES ('Coordenação de Aperfeiçoamento de Pessoal de Nível Superior') for a fellowship to Paulo G. M. A. Martins (23038.008980/2013-90), and FAPEMIG ('Fundação de Amparo à Pesquisa do Estado de Minas Gerais') for the financial support. In addition, the authors express appreciation to Frederico Dayrell Gomes da Costa for providing data from the dairy enterprise. Last but not least, gratitude is extended to Dr. Aldrin V. Pires (in memoriam), who sadly passed away before the submission of this work, and helped with the statistical analyses.

\section{References}

Almeida, R., Ramires, C. H., Jerszurki, D., Navarro, R. N., \& Ostrensky, A. (2009). Índices nutricionais e econômicos de rebanhos leiteiros de alta produtividade na região de Arapoti, Paraná. Proceedings of the 46th Reunião da Sociedade Brasileira de Zootecnia. Maringá, PR, Brazil: Universidade Estadual de Maringá.

Beretta, V., Lobato, F. P., \& Mielitz, N. (2001). Produtividade e eficiência biológica de sistemas pecuários de cria diferindo na idade das novilhas ao primeiro parto e na taxa de natalidade do rebanho no Rio Grande do Sul. Revista Brasileira de Zootecnia, 30, 1278-1286. https://doi.org/10.1590/S1516-35982001000500022

Camilo Neto, M., Campos, J. M. S., Oliveira, A. S., \& Gomes, S. T. (2012). Identification and quantification of benchmarks of milk production systems in Minas Gerais. Revista Brasileira de Zootecnia, 41, 2279-2288. https://doi.org/10.1590/S1516-35982012001000020

Dekkers, J. C. M., Ten Hag, J. H., \& Weersink, A. (1998). Economic aspects of persistency of lactation in dairy cattle. Livestock Production Science, 53, 237-252. https://doi.org/10.1016/S0301-6226(97)00124-3

Facó, O., Lôbo, R. N. B., Martins Filho, R., Martins, G. A., Oliveira, S. M. P., \& Azevêdo, D. M. M. R. (2008). Efeitos genéticos aditivos e não-aditivos para características produtivas e reprodutivas em vacas mestiças Holandês × Gir. Revista Brasileira de Zootecnia, 37, 48-53. https://doi.org/10.1590/S1516-3598200800 0100006

FAEMG. (1996). Diagnóstico da Pecuária Leiteira do Estado de Minas Gerais: Relatório de Pesquisa. Belo Horizonte, MG, Brazil: Federação da Agricultura do Estado de Minas Gerais.

FAEMG. (2006). Diagnóstico da Pecuária Leiteira do Estado de Minas Gerais em 2005: Relatório de Pesquisa. Belo Horizonte, MG, Brazil: Federação da Agricultura do Estado de Minas Gerais.

FAO, \& IDF. (2011). Guide to Good Dairy Farming Practice. Animal Production and Health Guidelines No. 8. Rome, Italy: Food and Agriculture Organization of the United Nations and International Dairy Federation.

FAO. (2013). FAO Statistical Yearbook 2013 World Food and Agriculture. Rome, Italy: Food and Agriculture Organization of the United Nations.

Faria, V. P., \& Silva, S. C. (1996). Fatores biológicos determinantes na pecuária leiteira. Proceedings of the Simpósio Internacional O Futuro dos Sistemas de Produção de Leite (pp. 77-89). Juiz de Fora, MG, Brazil: CNPGL/EMBRAPA.

Farm Financial Standards Council. (2011). Financial Guidelines for Agricultural Producers. Naperville, IL, USA: Farm Financial Standards Council.

Fassio, L. H., Reis, R. P., \& Geraldo, L. G. (2006). Desempenho técnico e econômico da atividade leiteira em Minas Gerais. Ciência e Agrotecnologia, 30, 1154-1161 https://doi.org/10.1590/S1413-705420060006 00018

Ferguson, C. E. (1975). Microeconomic Theory (The Irwin series in economics) (4th ed.). Willowbrook, IL, USA: Irwin Professional Publishing.

IBGE. (2008). Pesquisa Pecuária Municipal 2006-2007. Brasília, DF, Brazil: Instituto Brasileiro de Geografia e Estatística. 
IBGE. (2014). Indicadores IBGE Estatística da Produção Pecuária. Brasília, DF, Brazil: Instituto Brasileiro de Geografia e Estatística.

IFCN Dairy Report. (2008). For a better understanding of milk production world-wide (International Farm Comparison Network) (p. 214). Kiel, Germany: IFDN Dairy Research Center.

Inchaisri, C., Jorritsma, R., Vos, P. L. A. M., van der Weijden, G. C., \& Hogeveen, H. (2010). Economic consequences of reproductive performance in dairy cattle. Theriogenology, 74, 835-846. https://doi.org/ 10.1016/j.theriogenology.2010.04.008

Jarret, J. (1997). Produção de leite de qualidade. In Proceedings of the Simpósio Internacional Sobre Produção Intensiva de Leite (pp. 34-45). Belo Horizonte, MG, Brazil: FMVZ Univ. São Paulo.

Leite, L. A., Barbosa, F. A., \& Campos, W. E. (2006). Controle zootécnico e econômico na pecuária leiteira. In A. C. G. R. Neiva, \& J. N. M. Neiva (Eds.), Do Campus para o Campo, Tecnologias para a Produção de Leite (pp. 111-134). Araguaína, TO, Brazil: Universidade Federal de Tocantins.

Lopes, M. A., \& Carvalho, F. M. (2001). Custo de produção e análise de rentabilidade na pecuária leiteira. Proceedings of the Simpósio Goiano sobre Manejo e Nutrição de Bovinos (pp. 243-278). Goiânia, GO, Brazil: Universidade Federal de Goiás.

Lopes, M. A., Demeu, A. A., Nogueira, T. M., \& Santos, N. R. S. (2012). Avaliação da rentabilidade de dois sistemas de produção na recria e terminação de bovinos de corte na região de Lavras-MG: estudo de casos. Informações Econômicas, 42, 44-53.

Lopes, M. A., Demeu, F. A., Santos, G., \& Cardoso, G. M. (2009). Impacto econômico do intervalo de partos em rebanhos bovinos leiteiros. Ciência e Agrotecnologia, 33, 1908-1914. https://doi.org/10.1590/S1413-70542 009000700036

Lopes, M. A., Lima, A. L. R., Carvalho, F. M., Reis, R. P., Santos, I. C., \& Saraiva, F. H. (2004). Controle gerencial e estudo da rentabilidade de sistemas de produção de leite na região de Lavras (MG). Ciência e Agrotecnologia, 28, 883-892. https://doi.org/10.1590/S1413-70542004000400022

Lopes, M. A., Santos, G., Resende, M. C., Carvalho, F. M., \& Cardoso, M. G. (2011). Estudo da rentabilidade de sistemas de produção de leite no município de Nazareno, MG. Ciência Animal Brasileira, 12, 58-69. https://doi.org/10.5216/cab.v12i1.7725

Mancio, A. B., Schiffler, E. A., \& Londono-Hernández, F. I. (1999). Eficiência técnica e econômica de quatro empresas de produção de leite da região de São Carlos, SP. Arquivo Brasileiro de Medicina Veterinária e Zootecnia, 51, 283-286. https://doi.org/10.1590/S0102-09351999000300015

Marques, V. M., Reis, R. P., Sáfadi, T., \& Reis, A. J. (2002). Custo e escala na pecuária leiteira: estudos de casos em Minas Gerais. Ciência e Agrotecnologia, 26, 1027-1034.

Matsunaga, M., Bemelmans, P. F., Toledo, P. E. N., Dulley, R. D., Okawa, H., \& Pedroso, I. A. (1976). Metodologia de custo de produção utilizado pelo IEA. Agricultura em São Paulo, 23, 123-139.

Moraes, A. C. A., Coelho, S. G., Ruas, J. R. M., Ribeiro, J. C. V. C., Vieira, F. A. P., \& Menezes, A. C. (2004). Estudo técnico e econômico de um sistema de produção de leite com gado mestiço F1 Holandês-Zebu. Arquivo Brasileiro de Medicina Veterinária e Zootecnia, 56, 745-749. https://doi.org/10.1590/S0102-09352 004000600008

Nogueira, M. P. (2004). Gestão dos custos e avaliação de resultados: Agricultura e pecuária. Bebedouro, SP, Brazil: Scot Consultoria.

Oliveira, A. S., Cunha, D. N. F. V., Campos, J. M. S., Vale, S. M. L. R., \& Assis, A. J. (2007). Identificação e quantificação de indicadores-referência de sistemas de produção de leite. Revista Brasileira de Zootecnia, 36, 507-516. https://doi.org/10.1590/S1516-35982007000200030

Oliveira, T. B. A., Figueiredo, R. S., Oliveira, M. W., \& Nascif, C. (2001). Índices técnicos e rentabilidade da pecuária leiteira. Scientia Agricola, 58, 687-692. https://doi.org/10.1590/S0103-90162001000400006

Potkanya, M., \& Krajcirova, L. (2015). Quantification of the volume of products to achieve the break-even point and desired profit in non-homogeneous production. Procedia Economics and Finance, 26, 194-201. https://doi.org/10.1016/S2212-5671(15)00811-4

Reis, R. P. (2002). Fundamentos de economia aplicada. Lavras, MG, Brazil: UFLA/FFAEPE. 
Reis, R. P., Medeiros, A. L., \& Monteiro, L. A. (2001). Custos de produção da atividade leiteira na região sul de Minas Gerais. Organizações Rurais \& Agroindustriais: Revista de Administração da UFLA, 3, 45-52.

Schiffler, E. A., Mancio, A. B., Gomes, S. T., \& Queiroz, A. C. (1999). Efeito da escala de produção nos resultados de produção de leite B no estado de São Paulo. Revista Brasileira de Zootecnia, 28, 425-431. https://doi.org/10.1590/S1516-35981999000200029

Shoemaker, D., Eastridge, M., Breece, D., Woodruff, J., Rader, D., \& Marrison, D. (2008). 15 Measures of Dairy Farm Competitiveness (Bulletin 864). Columbus, OH, USA: The Ohio State University.

Vilela, D., Lima, J. A., Resende, J. C., \& Verneque, R. S. (2006). Desempenho de vacas da raça Holandesa em pastagem de coastcross. Revista Brasileira de Zootecnia, 35, 555-561. https://doi.org/10.1590/S1516-359 82006000200031

Yamaguchi, L. C. T., Carneiro, A. V., \& Carvalho, G. R. (2008). Sistemas Referenciais de Produção de Leite na Região Norte de Minas Gerais: Análise de Custos por Setores de Produção e Serviços. Boletim Técnico CBLeite 5 (pp. 18-21). Juiz de Fora, MG, Brazil: Embrapa-CNPGL.

\section{Copyrights}

Copyright for this article is retained by the author(s), with first publication rights granted to the journal.

This is an open-access article distributed under the terms and conditions of the Creative Commons Attribution license (http://creativecommons.org/licenses/by/4.0/). 